\title{
BASED SANITATION
}

Eve Mackinnon (evemackinnon7@gmail.com) is a PhD researcher, Dr Luiza C. Campos

(I.campos@ucl.ac.uk) is Associate Professor, and Dr Priti Parikh is Senior Lecturer in the Department of Civil, Environmental and Geomatic Engineering, UCL Environment Institute, UK; Niteen Sawant is Project leader/Risk assessor at Unilever's Environmental Safety and Assurance Centre (C) Practical Action Publishing, 2019, www.practicalactionpublishing.org http://dx.doi.org/10.3362/1756-3488.18-00025, ISSN: 0262-8104 (print) 1756-3488 (online)

\section{$[\mathrm{CH}]$ Classifying occupational exposure risks and recommendations for their control in container-based sanitation systems}

\author{
[AU]EVE MACKINNON, LUIZA C. CAMPOS, P. PARIKH, and NITEEN SAWANT
}

[ABS]This practice paper concerns the management of occupational exposure risks during the operation of container-based sanitation (CBS) systems. The paper reports on findings based on three different CBS systems. An exposure risk assessment was conducted in each case study following a methodology adapted from the WHO Sanitation Safety Planning (SSP) Framework. The specific methods of data collection comprised a risk assessment workshop, as well as in-depth interviews and sanitary surveys to support and explain the findings from the risk assessment workshops. The analysis of the occupational exposure risks classified exposure risks into four categories of 'drivers' of exposure risk. These 'drivers' were supported by relevant secondary literature of exposure risk studies. The classification of hazardous events and exposure risks in CBS systems recognized: (1) the role of technical design and maintenance and condition of facilities, as well as manual aspects of labour; followed by (2) human behaviour; (3) system performance; and (4) physical environment. This classification is expected to simplify the exposure risk management process and provides a framework for the subsequent identification and management of occupational exposure in CBS systems. The framework is an additional tool within the sanitation safety planning toolkit to measure and manage exposure risks and thereby ensure safe sanitation performance. This research addresses a current knowledge gap in occupational exposure risks in CBS systems. The integration and use of these results in an adapted SSP framework may build a stronger business case for the adoption of CBS systems in city-wide urban sanitation sector planning.

[KEY]Keywords: container-based sanitation, occupational exposure risk, health and safety, risk assessment and management, public health risk, sanitation safety planning

THE GLOBAL DISEASE BURDEN caused by inadequate water, sanitation, and hygiene provision is put at 64.2 million disability-adjusted life years (DALYs) (Cairncross et al., 2013) and is linked to multiple negative health impacts such as infant mortality, stunting, and chronic diseases (Humphrey, 2009; Garenne, 2010; Masibo and Makoka, 2012), while constraining social and economic development. In response, the Sustainable Development Goal (SDG) 6.2 sets out to achieve universal sanitation access by 2030 to reduce the burden of diseases attributed to poor sanitation. Container-based sanitation (CBS) is an innovative technology that enables the provision of scalable, low-cost sanitation services to populations currently unserved by safe sanitation solutions (Tilmans et al., 2016). A fundamental principle of operation of CBS is that human waste (excreta and urine) is safely contained, collected, and transported in portable and sealable containers for treatment in a central 


\section{BASED SANITATION}

facility. After treatment to remove pathogens from the excreta and urine, application of the treated waste in the form of soil conditioners or solid fuels, among others, is possible. Along the CBS supply chain, certain activities involving collection and service workers could potentially result in human exposure to faeces and pathogens. This practice paper explores the management of occupational exposure risks based on three different CBS systems. In each case study an exposure risk assessment was conducted following a methodology adapted from the guidance in WHO sanitation safety plans.

Plausible health risks to workers in CBS systems arise from exposure to the same classes of pathogenic microorganisms that cause the significant infectious disease burden due to poor sanitation coverage. Pathogenic microorganisms are the principal hazard in excreta, while crosscontamination in urine-diversion sanitation systems is thought to result in the occurrence of pathogens in urine (WHO, 2006; Bischel et al., 2015). It is well established that exposure to a number of different disease agents found in excreta transmits enteric infections, leading to acute infectious diarrhoeal diseases, chronic infections resulting in malnutrition, undernutrition, and other complications (such as respiratory illnesses including asthma caused by inhalation of dead or living organisms), skin infections and eye infections (Table 1). Exposure results when pathogens are released due to hazardous events (HE) and reach a human host or receptor (Stenström et al., 2011) via transmission pathways. Exposure can occur at many points along the CBS system chain (Figure 1).

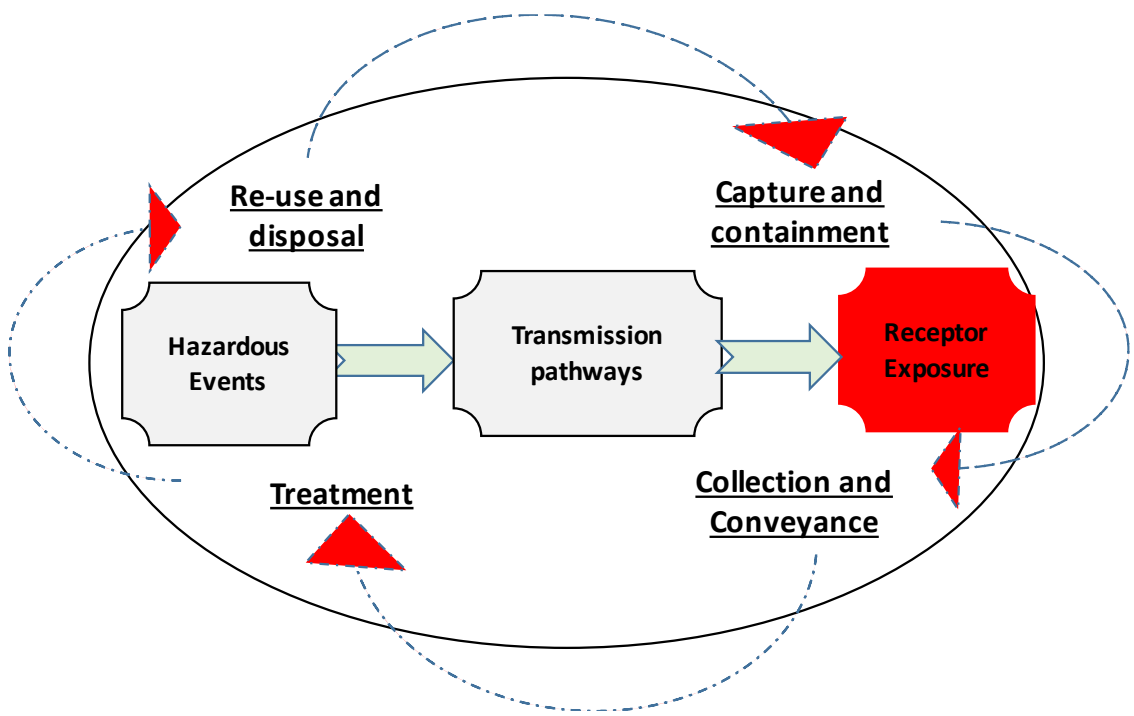

[CAP]Figure 1 Conceptual model of exposure within the CBS system

[S]Source: author

The prevalence of enteric diseases in the community will determine the type and quantity of pathogens present in the excreta and subsequent risks to health in exposed individuals. The pathogen load in excreta can be significant in developing countries with endemic diarrhoeal diseases and during epidemics of enteric diseases (Kotloff et al., 2013).

[CAP]Table 1 Expected pathogens in human excreta and associated disease outcomes

\begin{tabular}{|l|l|}
\hline Pathogen group & Clinical pathology and disease \\
\hline Viruses & Infectious hepatitis \\
\hline Hepatitis A and E & Enteritis, vomiting and diarrhoea \\
\hline Rotavirus
\end{tabular}




\section{BASED SANITATION}

\begin{tabular}{|c|c|}
\hline Adenovirus, enteroviruses & Enteritis, numerous conditions \\
\hline \multicolumn{2}{|l|}{ Bacteria } \\
\hline Campylobacter jejuni/coli & Campylobacteriosis: diarrhoea, cramping, abdominal pain, fever, nausea, arthritis \\
\hline Escherichia coli (E. coli) & Diarrhoea \\
\hline Salmonella typhi/paratyphi & Para/typhoid fever \\
\hline Salmonella spp. & Salmonellosis - diarrhoea, fever, abdominal cramps \\
\hline Shigella spp. & Dysentery (bloody diarrhoea) \\
\hline Vibrio cholerae & Cholera: watery diarrhoea, lethal if severe and untreated \\
\hline \multicolumn{2}{|l|}{ Parasitic protozoa } \\
\hline Giardia intestinalis & Giardiasis - diarrhoea, abdominal cramps, malaise, weight loss \\
\hline Cryptosporidium parvum & Cryptosporidiosis - watery diarrhoea, abdominal cramps and pain \\
\hline Entamoeba histolytica & $\begin{array}{l}\text { Amoebiasis - often asymptomatic, dysentery, abdominal discomfort, fever, chills. Colonic } \\
\text { ulceration, amoebic dysentery }\end{array}$ \\
\hline \multicolumn{2}{|l|}{ Helminths } \\
\hline Hookworm & Hookworm infection: rash, cough, anaemia, protein deficiency \\
\hline Schistosoma & Schistosomiasis \\
\hline Ascaris & $\begin{array}{l}\text { Ascariasis: generally no, or few symptoms, wheezing, coughing, fever, enteritis, pulmonary } \\
\text { eosinophilia }\end{array}$ \\
\hline
\end{tabular}

[S]Source: adapted from Feacham et al., 1983 and Schoenning and Stenström, 2004

The potential occupational health risks related to excreta and waste water management are well described in relation to aspects of traditional sewered sanitation systems (Feacham et al., 1983). There is also evidence of occupational exposure to a variety of pathogens among refuse handling and composting workers, presenting a high risk of infections to workers both from the developed world (Giusti, 2009; Avery et al., 2012; Haagsma et al., 2012; Pearson et al., 2015) and developing countries (Rongo et al., 2004; Bleck and Wettberg, 2012). In comparison, the literature examining occupational exposures to excreta-related pathogens, as a result of on-site sanitation systems, is limited. Use and emptying of pit latrines, bucket latrines, and other on-site sanitation systems are typically associated with significant health risks and are categorized as 'unimproved' forms of sanitation (WHO, 2017). These types of sanitation are not comparable to CBS system processes, that 'incorporate measures which isolate excreta from human contact throughout the entire chain of collection, transport and treatment' (Tilmans et al., 2016). Therefore, an examination of hazardous events, risk factors, and potential health impacts to workers in CBS systems is required. Where risks in CBS have been assessed, this is either not based on empirical evidence (Stenström et al., 2011) or does not quantify the occupational exposure risk. Examples include assessment of the re-use of compost in urine diversion dry toilets (UDDT) systems in Sweden (Höglund, 2001) or the risk of transmission of contamination from household CBS systems to stored water at household level (Russel et al., 2015). Barring these preliminary studies, there is little published literature describing the potential exposure risks to CBS operators or approaches to investigate risks.

This evidence gap may in part be due to the fact that the practical implementation of CBS in certain communities is at a very early stage. It may also reflect how certain occupations, such as cleaning, associated with dirt and waste, are marginalized and often make up part of the informal economy and thus make the understanding of health risks difficult to manage and quantify (Swuste and Eijkemans, 2002; Tregenza, 2009). In response to this gap, this research aimed to perform a 


\section{BASED SANITATION}

preliminary investigation to identify and describe the exposure risks posed to operators engaged in the operation and maintenance of CBS systems. We sought to uncover the principal risk factors and recommend relevant control measures to contribute to the safe operation of CBS systems. This practice paper describes preliminary findings of assessments of exposure risks to excreta-related pathogens to front-line staff from three case studies conducted with private sector, nongovernmental organizations providing CBS services operating in Kenya, India, and London.

\section{[A]Methodology}

The overall objective of the study was to characterize operator exposure risks to excreta-related pathogens during performance of duties in CBS systems. We purposively selected three case studies of CBS systems, described in Table 2, targeted for their ability to provide relevant descriptions of the exposure in real life contexts. The case studies also yielded relevant insights for developing an approach for exposure risk assessment and management in CBS systems (Baxter and Jack, 2008). The risk assessment methodology developed iteratively and refinements were made to improve the data collection and analysis techniques following completion of each case study.

[CAP]Table 2 Description of the container-based sanitation studied

\begin{tabular}{|l|l|l|l|}
\hline Description & Sanivation & Canal boats & $\begin{array}{l}\text { Whatever The Need } \\
\text { India Services (WTNIS) }\end{array}$ \\
\hline Location & Naivasha, Kenya & London, UK & Pondicherry, India \\
\hline Date of study & July 2016 & March 2017 & January 2018 \\
\hline Number of users & 100 households & Est. 300 houseboats & 50 shared toilets \\
\hline Type of organization & $\begin{array}{l}\text { Sanitation social } \\
\text { enterprise }\end{array}$ & Private households & $\begin{array}{l}\text { Local non- } \\
\text { governmental } \\
\text { organization }\end{array}$ \\
\hline Modality of CBS unit & $\begin{array}{l}\text { Urine diversion dry } \\
\text { toilet (pedestal) }\end{array}$ & $\begin{array}{l}\text { Urine diversion dry } \\
\text { toilet (pedestal) }\end{array}$ & $\begin{array}{l}\text { Urine diversion dry } \\
\text { toilet (squatting) }\end{array}$ \\
\hline Anal cleansing method & Wiping & Wiping & Water \\
\hline Collection service & $\begin{array}{l}\text { Serviced collection } \\
\text { (weekly) }\end{array}$ & $\begin{array}{l}\text { Householders transfer } \\
\text { full containers to } \\
\text { disposal/treatment } \\
\text { point }\end{array}$ & $\begin{array}{l}\text { Serviced collection } \\
\text { (weekly) }\end{array}$ \\
\hline $\begin{array}{l}\text { Treatment techniques } \\
\text { employed }\end{array}$ & Pasteurization & $\begin{array}{l}\text { Aerobic composting } \\
\text { or direct disposal in } \\
\text { landfill }\end{array}$ & Composting \\
\hline Re-use and disposal & Fuel (briquettes) & $\begin{array}{l}\text { Compost, nothing } \\
\text { Compost/soil }\end{array}$ & $\begin{array}{l}\text { Comditioner } \\
\text { condion }\end{array}$ \\
\hline
\end{tabular}

The exposure risk assessments were conducted using the guidance adapted from the Sanitation Safety Planning (SSP) Framework (WHO, 2016). The SSP refers to a comprehensive management framework for exposure risks; however, since we were not implementing control measures or improvement plans we followed the first three steps:

1. constructing a system map;

2. listing potential hazardous events $(\mathrm{HE})$ - defined as a process by which pathogens are released into the environment (Figure 1) - transmission pathways, and specifying exposure groups;

3. ranking the exposure risks posed by HE using a simple numerical risk matrix. 


\section{BASED SANITATION}

The system diagrams defined the boundary of the CBS system and within each component we identified the transformation and storage of different waste materials, specified exposure groups and sequencing of activities and processes. System diagrams were also prepared to annotate the steps and processes undertaken. Data collection was performed by direct observation and transect walks at both a household and a facility level to validate the system maps. Potential HE and transmission pathways were observed during transect walks informing potential exposure risks to operators. Lastly, participatory assessment methodologies (group work) informed the risk ranking and took into consideration the presence of control measures in the determination of the likelihood of the HE. For this assessment, exposure risk was understood as a product of the likelihood (frequency) of a particular exposure incident and the severity of exposure in terms of health effects. The likelihood of exposure frequency was time-bound (daily, weekly, monthly, yearly, less than yearly). The severity of exposure considered the infectious potential and pathogen load of the exposure event and potential health consequences. A risk matrix combined the numerical values assigned to likelihood and severity to determine the risk level of each HE. A traffic light system adapted from the SSP applied a low, medium, and high-risk status to each event. Low risk events are those with no anticipated health effects and no action required but where the situation should be monitored; medium risks refer to those events where moderate health effects (e.g. fever, headache, diarrhoea, small injuries) or unease (e.g. noise, malodours) may result; high risk events are those that may result in acute and/or chronic illness and immediate actions are needed to minimize the risk (WHO, 2016). In addition, in two of the case studies, sanitary surveys were conducted which assessed indicators of hazardous events and exposure pathways and these were assigned a numerical scale. In total, we sampled 20 and 12 household and community toilet units, respectively, to understand exposure risks to operators at capture and containment. In Kenya and London, we undertook 12 in-depth interviews with operators to gain a deeper insight into the drivers of exposure risks through personal narratives of exposure and individual perceptions of health risks. The interview transcripts were coded for analytical themes using Nvivo software version 10.

\section{[A]Process}

To bring clarity to the complexity of exposure risks in CBS systems the analytical process used a simple framework to categorize exposure risk data according to four causal mechanisms.

- Equipment or hardware failures (Hurst, 1998) include exposure risks that are associated with physical breakdown in equipment or hardware, for example due to technical faults, lack of maintenance, and general wear and tear.

- Behavioural/person error (Hurst, 1998; HSE, 1999; Michie et al., 2011) includes exposure risks that arise due to a lack of risk awareness or related to individual perceptions of risk. Also includes exposure risks resulting from wilful violations of acceptable conduct, or unintentional mistakes and lapses of concentration.

- System performance and operational failures (Gwebu, 2003; Worku and Muchie, 2012) refer to less tangible aspects of exposure risks that arise when system performance suffers due to inadequate systems management or a poor internal safety culture which manifests, for example, in poor staff health management or weak internal and external monitoring and regulations. 


\section{BASED SANITATION}

- Physical/seasonal and environmental factors (Aroua, 2016; Kwiringira et al., 2016) refer to risks of exposure arising from physical hazards, such as flooding, disease epidemics or aspects of geomorphology which increase risks.

This classification of exposure to causal mechanisms was based on an extensive review of the literature on factors affecting faecal-oral transmission, and on existing frameworks of disease and exposure risk analysis (Mayer, 1986; Gretsch et al., 2016). This classification was complemented by analysis of the qualitative data collected from the in-depth interviews with operators and stakeholders.

\section{[A]Results and discussion}

\section{[B]Hazardous events and exposure risks}

All the CBS systems collected excreta and urine (and wash water) in sealable and removable containers that were transported to a separate facility for disposal or treatment. In terms of exposure groups, we identified the following categories of operators who perform a variety of activities across the range of CBS operations including those who:

- clean and maintain the hygiene of CBS units (at a household and community level);

- collect and empty CBS units from household or community locations;

- drive the collection vehicles;

- perform treatment and waste processing activities.

Unsurprisingly, the three CBS system maps exhibited a mix of similarities and differences of processes and activities. It is beyond the scope of this paper to fully describe all the system processes illustrated in Annex 1. Key differences emerged in the waste flows linked to anal cleansing practices and processes for subsequent collection and transport use. Collection modalities varied depending on whether householders themselves transferred full waste containers to points for disposal and/or treatment, or whether specialized (and paid for) waste collection service existed. Treatment processes also varied between solar pasteurization and processing into fuel briquettes and aerobic thermophilic composting (Annex 1).

The identification of HE revealed numerous potential exposure risks to operators occurring at various points along the CBS system linked to the collection, transport, and treatment of urine, faecal solids, and black water (Table 3). Primary data for the hazard identification comes from a separate quantitative risk exposure of level of $E$. coli on CBS contact surfaces as an indicator of faecal contamination modelled with operator activity to estimate level of hand contamination (paper is in process). During the emptying and cleaning of toilets the highest exposure risks resulted from frequent handling of dirty toilet surfaces, from accidental hand contact with faecal material, and from inhalation of particles aerosolized during sweeping or emissions from unsealed containers (Table 3). Cleaning staff in general faced high risks due to frequent exposure to dirty toilets, and a lack of protection or training. Cleaning staff also required specialized hand hygiene facilities to practise hand hygiene given the mobile working environment. We also observed that the requirement for operators to remove internal waste collection containers from households, performed multiple times per day, led to cumulative exposure risks which were higher than exposure risks posed to householders when removing their own collection cartridge for collection. During the container transportation the highest exposure risks to operators resulted from spillages of waste materials during transport onto surfaces and floors (Table 3). The exposure risks during 


\section{BASED SANITATION}

treatment activities to operators depended on the nature of the treatment system. High risk exposures were associated with composting treatment activities occurring during the mixing of compost due to the inhalation of aerosolized pathogens and bio-aerosols (Table 3). Medium risk exposures to operators resulted from spillages while manually evacuating excreta from collection bags or containers for further treatment processes. Overall, at each system component, a lack of compliance to safety protocols (cleaning, disinfection, and use of personal protective equipment (PPE)) and lack of adherence to proper hand hygiene and food hygiene, increased exposure risks and left workers vulnerable to pathogen exposure and infectious diseases.

\section{[B]Classification of exposure risks}

Hazardous events were classified according to common affinities with the four causal mechanisms described in the methodology and set out in Table 4. The first classification of hazardous events recognizes the role of technical/engineering design as well as the physicality and manual aspects of labour, maintenance and condition of facilities, and toilet equipment in pathogen exposure risks along the CBS system:

- The presence of 'dead spaces' and toilets which were difficult to disassemble, posed challenges for effective cleaning and disinfection and led to toilet surfaces remaining contaminated.

- Surface contamination was associated with the material of surfaces which varied from porous, unpainted wood to plastics enhanced with anti-microbial additives, and influenced cleaning efficacy.

- Specific aspects of toilet design including the urine pipe diameter, separator design, and child adapted design led to blockages of the urine diversion caused by a build-up of urea in the urine pipe and cross-contamination of the urine diversion by faecal matter.

- Aspects of facility design, such as inadequate access to handwashing hardware led to noncompliance (in particular with hand hygiene protocols) despite a good awareness and training.

- Poor zoning and/or separation in treatment facilities between contaminated and sterile areas allowed for cross-contamination of pathogens from high risk to low risks areas

- In general, poorly maintained equipment, for example collection containers, compromised the containment of waste and led to spillages during collection and transportation.

The second classification of hazardous events recognized the human dimension of hazardous events and exposure risk identified in the risk assessments:

- Mis-use of the equipment or PPE led to multiple exposure risks.

- Non-compliance with PPE including not wearing gloves at appropriate times.

- Non-compliance to standard operating procedures (SOPs) (e.g. manual sweeping, instead of mechanized cleaning of the facilities) led to aerosolization resulting in multiple exposure risks.

- Failure to adhere to proper hand hygiene procedures at critical points led to hand contamination and associated exposure risks.

- Exposure risks driven by lapses in concentration were difficult to identify but were assumed to occur, especially in regard to practising hand hygiene. 


\section{BASED SANITATION}

- Low perception of vulnerability or severity of risks posed by contact with faecal matter contributed to exposure risks.

The third classification of hazardous events recognizes that system performance and operational failures contribute to hazardous events and exposure risks. Overall, this is reflected by a lack of preventive management and monitoring, a poor internal safety culture, and an absence of critical SOPs:

- Inadequate staff health management referred to in staff interviews (a lack of proper health insurance, regular health checks or having received appropriate vaccinations) left workers vulnerable to infection risks post-exposure.

- Temporary or daily workers hired to perform potentially hazardous activities. These workers were more vulnerable to exposure risks; for example they were not able to access health checks and did not receive training.

- An absence of SOPs across the entire system chain led to poor performance, compliance, and staff awareness. (Cleaning and disinfection was rarely defined as a SOP and treatment and re-use SOPs were not standardized across the industry.)

- In certain contexts, cleaning staff (generally women) occupied a lower status than other staff (usually men) in the hierarchical organizational structure, meaning their voices may be marginalized in 'participatory' types of risk assessments.

- An absence of internal and external regulations and monitoring results in a lack of any motivation within the organizations to comply with safety measures.

- Exposure risks to workers involved with cleaning or servicing the toilets are augmented by the frequent and repetitive handling of the toilets (paper in process).

- High exposure risks via inhalation of bio-aerosols during agitation of bags (in particular from fungi) in the composting treatment activities.

The fourth classification recognizes the aspects of the physical environment as external causes of hazardous events and exposure risk. Seasonality, land use characteristics, and infrastructure were manifested in the case study as:

- Spillages during conveyance due to deterioration of road/transport routes.

- Sites in flooded areas or sites liable to flooding exacerbated exposure risks due to contact with highly contaminated flood water during collection and conveyance. 
[CAP]Table 3 Summary of potential exposure risks from results of hazard analysis in the three case studies of CBS systems. The hazard analysis summarizes the process steps, hazardous events, exposure routes, and existing control measures reported or observed at each system component

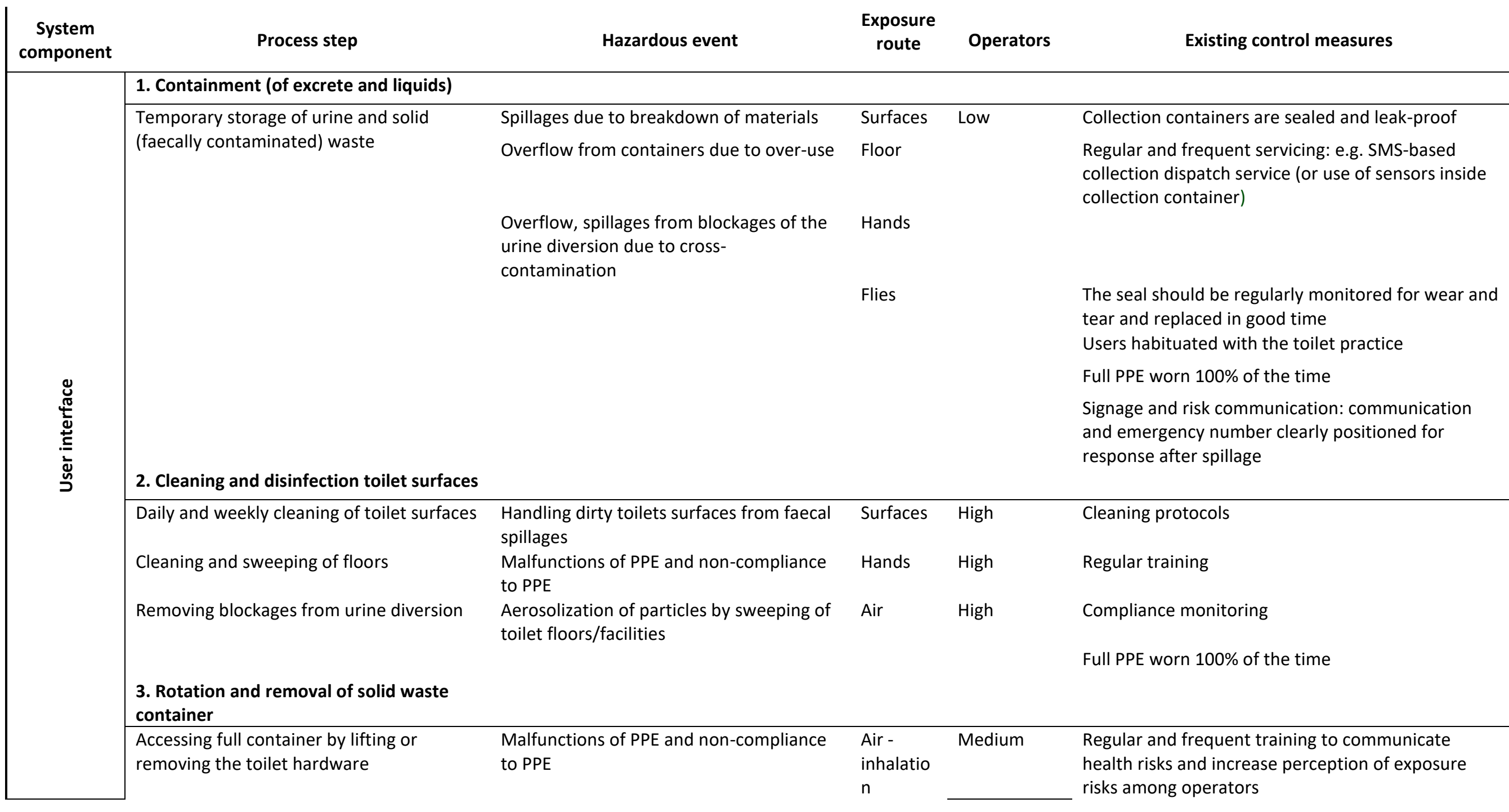


Removing full bag/container from under

toilet pedestal or squatting plate

Replacing the full container with an empty one

Sealing the full bag and placing into

collection vehicle
Airborne emissions from collection

containers agitated during removal

Spillages of raw waste from poorly sealed containers or overfilled

Handling contaminated containers

Hands
Air -

inhalatio

n

Flies

Surfaces

4. Rotation and removal of liquid waste container (if applicable)

Accessing full container by lifting or

removing the toilet hardware

Removing full container from under toilet

pedestal or squatting plate

Replacing the full container with a new

one

Sealing the full bag and placing into

collection vehicle

\section{Malf}

to PPE

Airborne emissions from collection

containers agitated during removal

Spillages of waste

Handling contaminated containers

Strong sealing mechanism (lid/cap/bag fastening)

for waste collection containers

Use of cover material on raw faecal waste

Containers directly placed onto the collection vehicle to reduce the risk of spillages and unsupervised collection containers in the local environment and exposure to people

Glove protocol: e.g. disposable latex gloves used where red gloves are not appropriate providing they are exchanged between households

Hand sanitization to prevent potential transfer of contamination between households on operator's gloves

Access to handwashing facilities; enabling behaviour change to encourage uptake and practise of handwashing

\section{Transportation}

ปั

\section{Loading full containers onto collection} vehicle
Spillages during transportation

Malfunctions of PPE and non-compliance

to PPE

Airborne emissions from collection

containers agitated during removal
Hands

Low

Surfaces
Covered collection vehicle to prevent leakage and environmental contamination

Washing and disinfection of vehicles with $0.2 \%$

chlorine solution while wearing PPE

Environmental spillage protocol (including

disinfection with $0.5 \%$ chlorine solution) 


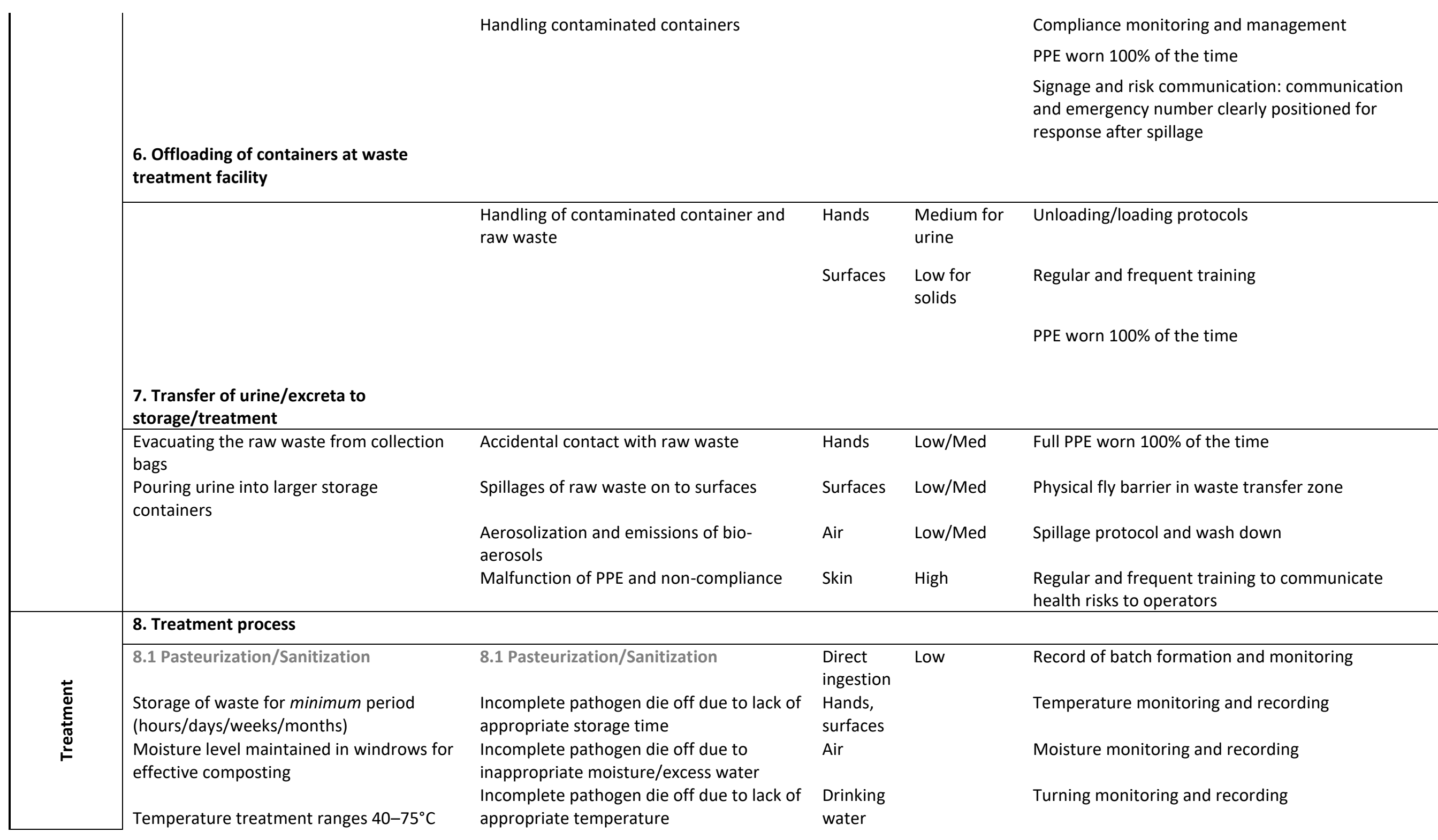




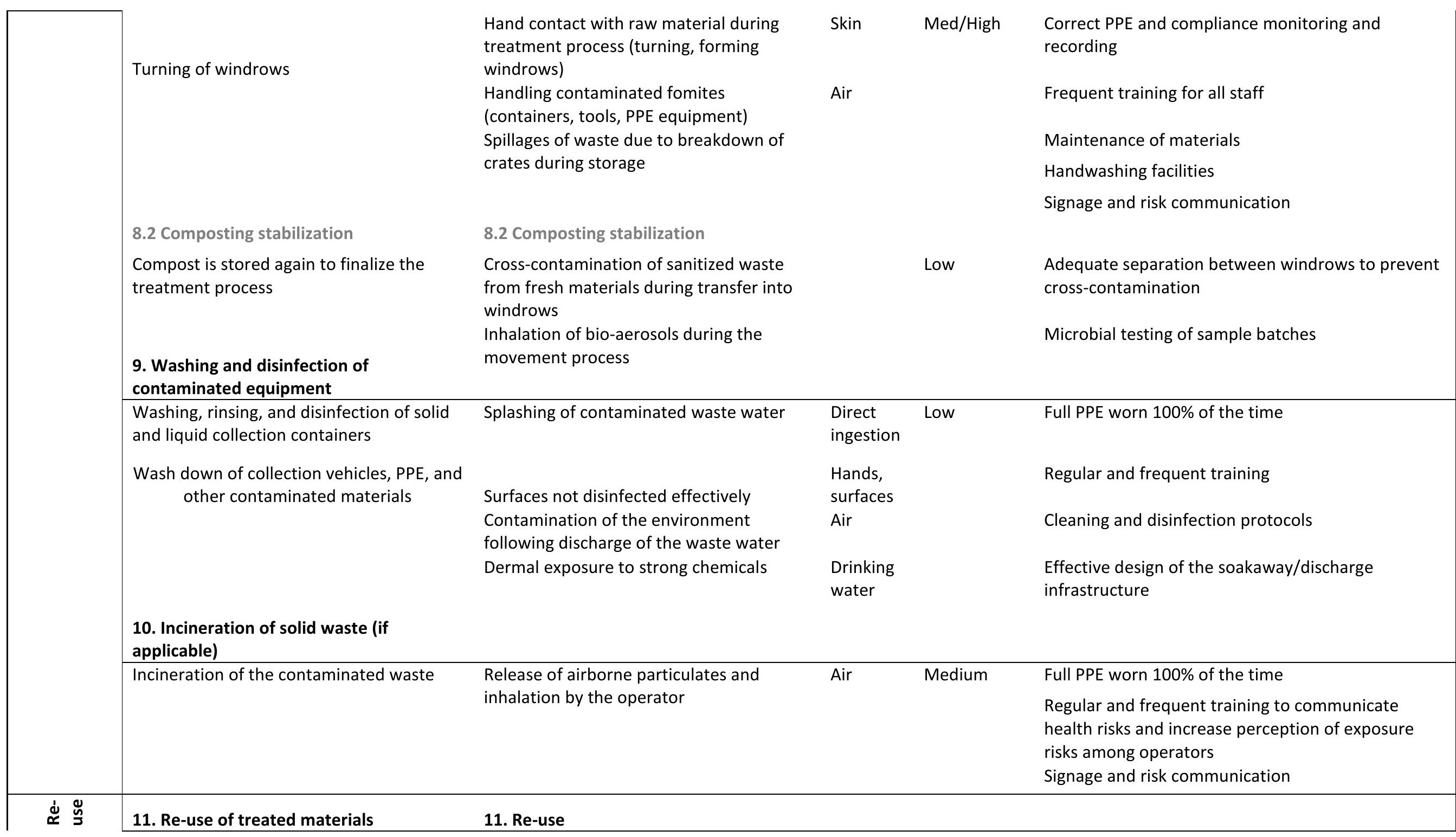




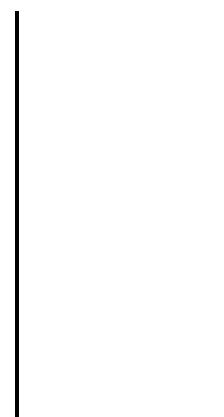

11.1. Spreading of compost onto fields

11.2. Use of harvested products
11.1. Spreading of compost onto fields Handling and ingestion of contaminated compost during spreading/application

Aerosols released during the

spreading/application

11.2. Use of harvested products

Consumption of contaminated vegetables
Hands, Negligible to

flies, soil operators

Air

Correct treatment procedures

Hand hygiene after farming activities

[NOTE]PPE: personal protective equipment 


\section{BASED SANITATION}

\section{[CAP]Table 4 Classification of hazardous events identified according to the four causal mechanisms of person error, equipment, regulatory and system safety culture, and physical seasonal and environmental variables. The sanitation step where these hazardous events occur is also indicated according to the legend: Sanitation step: 1 - user interface; 2 - collection and emptying; 3 - conveyance; 4 - treatment and re-use/disposal}

\section{Sanitation Step}

\section{Typologies of Hazardous Events (HE)}

\section{Person Error:}

\begin{tabular}{|c|c|c|c|c|}
\hline 1 & 2 & 3 & 4 & \\
\hline $\mathrm{x}$ & $\mathrm{x}$ & & & Surfaces contamination associated with mis - use (e.g. age related) \\
\hline \multirow[t]{2}{*}{$\mathrm{x}$} & $x$ & $\mathrm{x}$ & $x$ & Spillages onto surfaces and floors due to overflow of the collection containers from over-use \\
\hline & $\mathrm{x}$ & & & Spillages due to poor driving skills or driver error \\
\hline$x$ & $\mathrm{x}$ & & & Surface contamination associated with poor cleaning and disinfection behaviours \\
\hline$x$ & $\mathrm{x}$ & $\mathrm{x}$ & $x$ & Hands contamination due to lack handwashing/hand hygiene practices \\
\hline $\mathrm{x}$ & $\mathrm{x}$ & $\mathrm{x}$ & $\mathrm{x}$ & $\begin{array}{l}\text { Non-compliance with protocols. For example, sweeping the toilet during cleaning (not advised as per cleaning protocol) poses a risk to workers due } \\
\text { to agitation of aerolised organic and non-organic particles }\end{array}$ \\
\hline \multirow[t]{3}{*}{$\mathrm{x}$} & $\mathrm{x}$ & $\mathrm{x}$ & $\mathrm{x}$ & Non-compliance with PPE due to a low perception of risk or threats \\
\hline & & & & A lack of relevant skills or knowledge or a lapse in concentration or individual perception of risks, vulnerability or severity \\
\hline & $\mathrm{x}$ & & $\mathrm{x}$ & Illegal dumping of waste into the environment due to mis-practices \\
\hline \multicolumn{5}{|r|}{ Equipment/technical failure: } \\
\hline $\mathrm{x}$ & $\mathrm{x}$ & $\mathrm{x}$ & $\mathrm{x}$ & $\begin{array}{l}\text { Spillages due to failure of physical integrity of containers (open lids, broken sides) and poorly maintained collection containers compromised the } \\
\text { containment of waste a }\end{array}$ \\
\hline $\mathrm{x}$ & $\mathrm{x}$ & & & Spillages due to breakage of bags \\
\hline $\mathrm{x}$ & $\mathrm{x}$ & & & Spillages due to containers too small or under-designed \\
\hline & $\mathrm{x}$ & $\mathrm{x}$ & $x$ & Splash back during emptying due to poor (neck) design of urine containers \\
\hline $\mathrm{x}$ & & & & Urine spills into unit due to poor separator design \\
\hline $\mathrm{x}$ & & & & $\begin{array}{l}\text { A common technical failure in the design of some CBS systems was blockages of the urine diversion caused by a build-up of urea (pipe diameters } \\
\text { under }<32 \mathrm{~mm} \text { ) }\end{array}$ \\
\hline $\mathrm{x}$ & $\mathrm{x}$ & $\mathrm{x}$ & $\mathrm{x}$ & Unfavourable toilet design with dead spaces or difficult to dissemble, also posed cleaning challenges. \\
\hline $\mathrm{x}$ & $\mathrm{x}$ & $\mathrm{x}$ & $\mathrm{x}$ & $\begin{array}{l}\text { The extent of surface cleanliness was affected by materials used for toilets construction since certain types of materials (e.g. porous wood) } \\
\text { presented difficulties to clean. }\end{array}$ \\
\hline $\mathrm{x}$ & $\mathrm{x}$ & $\mathrm{x}$ & $\mathrm{x}$ & $\begin{array}{l}\text { Facilities lacked sufficient access to handwashing hardware and prevented compliance with hand hygiene protocols despite a good awareness and } \\
\text { training. }\end{array}$ \\
\hline & & $\mathrm{x}$ & $x$ & Incomplete combustion of waste during incineration due to low temperatures \\
\hline & & $\mathrm{x}$ & $x$ & Ineffective treatment mechanisms does not kill pathogens/microbes \\
\hline$x$ & $x$ & $\mathrm{x}$ & $x$ & PPE failure or not performing as expected (e.g breakages or poor equipment) \\
\hline & & $\mathrm{x}$ & $\mathrm{x}$ & Poor waste water/soak away design / efficacy \\
\hline \multicolumn{5}{|r|}{ Regulatory and system safety culture: } \\
\hline $\mathrm{x}$ & $\mathrm{x}$ & $\mathrm{x}$ & $\mathrm{x}$ & Redundant or ineffective PPE protocols \\
\hline $\mathrm{x}$ & $\mathrm{x}$ & & & $\begin{array}{l}\text { Urine or excreta from one household is inadvertently transmitted to another household (Cross contamination) due to poor emptying and } \\
\text { conveyance hygiene protocols. }\end{array}$ \\
\hline$x$ & $\mathrm{x}$ & $\mathrm{x}$ & $\mathrm{x}$ & Poorly implemented/inadequate/ineffective disinfection and treatment protocols \\
\hline \multirow[t]{2}{*}{$\mathrm{x}$} & $\mathrm{x}$ & $\mathrm{x}$ & $\mathrm{x}$ & Inadequate treatment due a lack of internal/external regulations \\
\hline & $\mathrm{x}$ & $\mathrm{x}$ & & Illegal tipping of untreated waste due to lack of internal/externa regulations \\
\hline $\mathrm{x}$ & $\mathrm{x}$ & $\mathrm{x}$ & $\mathrm{x}$ & Inadequate staff health management leaves workers vulnerable to infection risks post-exposure \\
\hline $\mathrm{x}$ & $\mathrm{x}$ & $\mathrm{x}$ & $\mathrm{x}$ & A lack of proper health insurance, regular health checks or having received appropriate vaccinations. \\
\hline $\mathrm{x}$ & $\mathrm{x}$ & $\mathrm{x}$ & $\mathrm{x}$ & $\begin{array}{l}\text { Hiring of temporary or daily workers to perform potentially hazardous activities was a significant breach of exposure safety management, as } \\
\text { workers are highly vulnerable to infections as they do not receive regular health checks }\end{array}$ \\
\hline $\mathrm{x}$ & $\mathrm{x}$ & $\mathrm{x}$ & $\mathrm{x}$ & $\begin{array}{l}\text { A failure to develop, train and apply critical SOPs. A lack of defined SOPs prevented specific training or compliance to protocols / staff awareness. } \\
\text { Cleaning and disinfection of toilets was rarely defined as a SOP and treatment and re-use protocols are not standardized across the industry }\end{array}$ \\
\hline $\mathrm{x}$ & $\mathrm{x}$ & $\mathrm{x}$ & $\mathrm{x}$ & $\begin{array}{l}\text { In certain contexts cleaning staff (women) occupied a lower status of other staff (men), in the hierarchical organizational structure, meaning their } \\
\text { voices maybe marginalized in 'participatory' types of risk assessments }\end{array}$ \\
\hline $\mathrm{x}$ & $\mathrm{x}$ & $\mathrm{x}$ & $\mathrm{x}$ & Absence of internal and external regulations and monitoring reduced pressure on organisations to comply to safety measures \\
\hline \multicolumn{5}{|r|}{ Physical/Seasonal/Environmental Variables: } \\
\hline \multirow{7}{*}{$\begin{array}{l}x \\
x\end{array}$} & $\mathbf{x}$ & & & Spillages during conveyance due to deterioration of road/transport routes \\
\hline & & $\mathrm{x}$ & $\mathrm{x}$ & Excreta (diarrhea) splashes onto handler during emptying due to low viscosity of waste \\
\hline & $\mathrm{x}$ & & & Diarrheal events/outbreaks of infectious diseases causes contamination on toilet surfaces \\
\hline & & & $\mathrm{x}$ & Wastewater/urine soakaways overflow due to extreme weather/flood events \\
\hline & $\mathrm{x}$ & & & Urine and excreta spills caused by deteoriation of road/transport routes \\
\hline & $\mathrm{x}$ & $\mathrm{x}$ & $x$ & Repetitive exposure to urine and excreta due to type and intensity of manual handling tasks \\
\hline & $\mathrm{x}$ & $\mathrm{x}$ & $x$ & Pathogens aerolised due to agitation/mechanisation of processes \\
\hline
\end{tabular}

[NOTE]SOP: standard operating procedure 


\section{BASED SANITATION}

\section{[B]Control measures}

Appropriate control measures exert influence over the specific drivers of exposure to reduce or prevent hazardous events. If no control measure could be applied at any given stage, ideally the process or step should be eliminated.

In CBS systems, relevant design controls are necessary to ensure the level of cleanliness, maintenance, and regular servicing to maintain the physical integrity and hygienic conditions of equipment and facilities. The concept of 'safety-guided design' aims to eliminate hazards from the design (Leveson, 2012). Annex 2 and Annex 3 refer to a list of minimum design parameters and maintenance and cleaning schedules for each CBS system, respectively. Minimum design specifications ensure cleanability, durability, usability adapted design (e.g. for children, people living with disability, women), isolation and containment for solid faecal waste (SFW) and liquid faecal waste (LFW), minimal dispersal through air, and appropriate risk signage and communication. An example of this is the ISO/IWA 24:2016 (en) standardization for non-sewered sanitation that aims to regulate and control safety within the sanitation sector (IWA, 2016). Behavioural controls are fundamentally based on processes occurring in the mind; therefore it is essential to understand these factors in order to correct or change behaviour (Contzen and Mosler, no date; Mosler, 2012). Behavioural control measures depend on the cause of risky behaviour; they may include training to increase relevant skills or knowledge, promoting habit formation to prevent lapses in concentration, and awareness raising to counter individual perception of risks, vulnerability or severity (Hurst, 1998). It is beyond the scope of this practice paper to develop specific behavioural controls which might counter non-compliance issues identified in the risk assessments as they are situated in the specific context. Controls related to system performance and operation should focus on the development and application of appropriate SOPs to ensure the functionality and performance of hardware and software elements. Specific controls must also ensure the proper adherence to, and enforcement of, staff health management. Lastly, maintaining effective leadership and frequent consultation supports staff empowerment and encourages staff to raise health and safety concerns. In regards to environmental and physical failures, control measures should focus on prevention and preparedness to protect staff during seasonal episodes and outbreaks of infectious diseases in the community. If activities are associated with particular high risks and no controls exist then substitution of activities might be considered an effective precaution, and is generally prioritized in risk management (Bleck and Wettberg, 2012).

\section{[A]Conclusions}

We have illustrated exposure risks arising from a combination of technical, behavioural, organizational, and environmental failures and identified appropriate control measures that can prevent or reduce exposure risks to the operators. CBS systems are complex, and therefore no study could attempt to standardize the exposure risks or variables that exist. The case studies represent 'snapshots' in time of the exposure risks responding to processes occurring. Any generalizations are naturally limited by the small sample size. The analysis conducted must be viewed with caution in recognition of the complexities and we urge further hazard analyses and research in this field, using similar methodological approaches. Indeed, we propose that further investigation into causal mechanisms, particularly behavioural determinants of exposure is important for developing appropriate control measures. Testing and verification of control measures is necessary to ensure that they lead to expected safety outcomes. 


\section{BASED SANITATION}

Despite these limitations, the approach adopted in this study applying a risk assessment framework is able to guide work on key issues. The case studies indicate how health risk from exposure during CBS operations fundamentally arises due to aspects of mismanagement and therefore does not 'just happen' - the findings support the hypothesis that appropriate risk management in CBS systems is able to prevent occupational health risks arising during the handling of faecal matter.

This is a key point since CBS has relevance in several situations, especially in 1) addressing the need for safe sanitation in urban populations currently unserved where unsewered household connections are not feasible; 2 ) providing sanitation services in emergency situations and temporary habitats; and 3) providing sanitation services in recreational/leisure residences. Future application of the risk framework to minimize potential health risks due to faecal pathogens in excreta would encourage the scale up and application of CBS systems.

Moreover, the analytical approach to risk assessment and classification for identifying the types of exposure risks is intended to make identification of potential HE and exposure pathways more visible to sanitation practitioners to ensure relevant control measures are utilized. This may also complement the need for standards and regulations governing CBS to ensure successful provision of safe sanitation alternatives to populations while ensuring the health and wellbeing of the service providers. In fact, we suggest that CBS service providers consider health and wellbeing of their workers as a key internal performance indicator (e.g. illness rates not exceeding general population).

\section{[A]References}

Aroua, N. (2016) 'Urban vulnerability and resiliency over water-related risks: a case study from Algiers', Water Science and Technology 73(5): 1145-54 <http://dx.doi.org/10.2166/wst.2015.588>.

Avery, L.M., Booth, P., Campbell, C., Tompkins, D., and Hough, R.L. (2012) 'Prevalence and survival of potential pathogens in source-segregated green waste compost', Science of the Total Environment 431: 128-38 <http://dx.doi.org/10.1016/j.scitotenv.2012.05.020>.

Baxter, P. and Jack, S. (2008) 'Qualitative case study methodology: study design and implementation for novice researchers', The Qualitative Report 13(4): 544-59.

Bischel, H.N., Özel Duygan, B.D., Strande, L., McArdell, C.S., Udert, K.M., and Kohn, T. (2015) 'Pathogens and pharmaceuticals in source-separated urine in eThekwini, South Africa', Water Research 85: 57-65 <http://dx.doi.org/10.1016/j.watres.2015.08.022>.

Bleck, D. and Wettberg, W. (2012) 'Waste collection in developing countries: tackling occupational safety and health hazards at their source', Waste Management 32(11): 2009-17 <http://dx.doi.org/10.1016/j.wasman.2012.03.025>.

Cairncross, S., Cumming, O., Jeandron, A., Rheingans, R., Ensink, J., Brown, J., and Cavill, S. (2013) DFID Evidence Paper: Water, Sanitation and Hygiene [online], DFID <http://r4d.dfid.gov.uk/Output/193434/Default.aspx> [accessed 11 April 2019].

Contzen, N. and Mosler, H. (no date) The Risks, Attitudes, Norms, Abilities, and Self-regulation (RANAS) Approach to Systematic Behavior Change [pdf], EAWAG Fact Sheet $<$ https://www.eawag.ch/fileadmin/Domain1/Abteilungen/ess/schwerpunkte/ehpsy/RANAS Metho dological Fact Sheets.pdf> [accessed 10 June 2019].

Feacham, R., Bradley, D.J., Garelick, H., and Mara, D.D. (eds.) (1983) Sanitation and Disease: Health Aspects of Excreta and Wastewater Management, Washington, DC: World Bank. 


\section{BASED SANITATION}

Garenne, M. (2010) 'Urbanisation and child health in resource poor settings with special reference to under-five mortality in Africa', Archives of Disease in Childhood 95(6): 464-8.

Giusti, L. (2009) 'A review of waste management practices and their impact on human health', Waste Management 29(8): 2227-39 <http://dx.doi.org/10.1016/j.wasman.2009.03.028>.

Gretsch, S.R., Ampofo, J.A., Baker, K.K., Clennon, J., Null, C.A., Peprah, D., and Reese, H. (2016) 'Quantification of exposure to fecal contamination in open drains in four neighborhoods in Accra, Ghana', Journal of Water and Health 14(2): 255-66.

Gwebu, T.D. (2003) 'Population, development, and waste management in Botswana: conceptual and policy implications for climate change', Environmental Management 31(3): 348-54.

Haagsma, J.a.,Tariq, L., Heederik, D.J., and Havelaar, A.H. (2012) 'Infectious disease risks associated with occupational exposure: a systematic review of the literature', Occupational and Environmental Medicine 69(2): 140-6 <http://dx.doi.org/10.1136/oemed-2011-100068>.

Höglund, C. (2001) 'Evaluation of microbial health risks associated with the reuse of sourceseparated human urine', PhD thesis, Royal Institute of Technology, Stockholm, Sweden.

HSE (1999) Reducing Error and Influencing Behaviour, Norwich: TSO.

Humphrey, J.H. (2009) 'Child undernutrition, tropical enteropathy, toilets, and handwashing', The Lancet 374(9694): 1032-5 <http://dx.doi.org/10.1016/S0140-6736(09)60950-8>.

Hurst, N.W. (1998) Risk Assessment The Human Dimensions, Letchworth, UK: Royal Society of Chemistry.

IWA (2016) Non-Sewered Sanitation Systems ISO/PC 305, London: IWA.

Kotloff, K.L., Nataro, J.P., Blackwelder, W.C., Nasrin, D., Farag, T.H., Panchalingam, S., and Wu, Y. (2013) 'Burden and aetiology of diarrhoeal disease in infants and young children in developing countries (the Global Enteric Multicenter Study, GEMS): a prospective, case-control study', The Lancet 382(9888): 209-22 <http://dx.doi.org/10.1016/S0140-6736(13)60844-2>.

Kwiringira, J., Atekyereza, P., Niwagaba, C., Kabumbuli, R., Rwabukwali, C., Kulabako, R., and Gunther, I. (2016) 'Seasonal variations and shared latrine cleaning practices in the slums of Kampala city, Uganda', BMC Public Health 16: 361.

Leveson, N. (2012) 'Safety-guided design', in Engineering a Safer World: Systems Thinking Applied to Safety, Cambridge, MA: MIT Press.

Masibo, P.K. and Makoka, D. (2012) 'Trends and determinants of undernutrition among young Kenyan children: Kenya Demographic and Health Survey; 1993, 1998, 2003 and 2008-2009', Public Health Nutrition 15(9): 1715-27.

Mayer, J. (1986) 'Ecological associative analysis', in M. Pacione (ed.), Medical Geography: Progress and Prospect, p. 64, London: Croom Helm.

Michie, S., van Stralen, M.M., and West, R. (2011) 'The behaviour change wheel: a new method for characterising and designing behaviour change interventions', Implementation Science 6(1): 42 $<$ http://dx.doi.org/10.1186/1748-5908-6-42>.

Mosler, H. (2012) 'A systematic approach to behavior change interventions for the water and sanitation sector in developing countries: a conceptual model, a review, and a guideline', International Journal of Environmental Health Research 3123 (August 2017) <http://dx.doi.org/10.1080/09603123.2011.650156>.

Pearson, C., Littlewood, E., Douglas, P., Robertson, S., Gant, T.W., and Hansell, A.L. (2015) 'Exposures and health outcomes in relation to bioaerosol emissions from composting facilities: a systematic review of occupational and community studies', Journal of Toxicology and Environmental Health. 


\section{BASED SANITATION}

Part B, Critical Reviews 18(1): 43-69 <http://dx.doi.org/10.1080/10937404.2015.1009961>.

Rongo, L.M.B., Barten, F., Msamanga, G.I., Heedrerik, D., and Dolmans, W.M.V. (2004) 'Occupational exposure and health problems in small-scale industry workers in Dar es Salaam, Tanzania: a situation analysis', Occupational Medicine 54(1): 42-46 <http://dx.doi.org/10.1093/occmed/kqh001>.

Russel, K., Tilmans, S., Kramer, S., Sklar, R., Tillias, D., and Davis, J. (2015) 'User perceptions of and willingness to pay for household container-based sanitation services: experience from Cap Haitien, Haiti', Environment and Urbanization 27(2): 525-40

<http://dx.doi.org/10.1177/0956247815596522>.

Schoenning, C. and Stenström, T.A. (2004) Guidelines for the Safe Use of Urine and Faeces in Ecological Sanitation Systems [pdf], EcoSanRes Report 2004-1, Stockholm: Stockholm Environment Institute $<$ http://www.ecosanres.org/pdf files/ESR Publications 2004/ESR1web.pdf $>$ [accessed 10 June 2019].

Stenström, T.A., Seidu, R., Ekane, N., and Zurbrügg, C. (2011) Microbial Exposure and Health Assessments in Sanitation Technologies and Systems [pdf], Stockholm Environment Institute $<$ www.ecosanres.org> [accessed 11 April 2019].

Swuste, P. and Eijkemans, G. (2002) 'Occupational safety, health, and hygiene in the urban informal sector of sub-Saharan Africa: an application of the Prevention and Control Exchange (PACE) program to the informal-sector workers in Healthy City projects', International Journal of Occupational and Environmental Health 8(2): 113-8 <http://dx.doi.org/10.1179/107735202800338920>.

Tilmans, S., Russel, K., Sklar, R., Page, L., Kramer, S., and Davis, J. (2016) 'Container-based sanitation: assessing costs and effectiveness of excreta management in Cap Haitien, Haiti', Environment and Urbanization 27(6): 89-104 <http://dx.doi.org/10.1177/0956247815572746>.

Tregenza, T. (2009) Preventing Harm to Cleaning Workers [pdf], Bilbao, Spain: European Agency for Safety and Health at Work <https://osha.europa.eu/en/publications/reports/TEWE09006ENC/view> [accessed 10 June 2019].

WHO (2006) Third Edition of the WHO Guidelines for the Safe Use of Wastewater, Excreta and Greywater in Agriculture and Aquaculture Guidance Note for National Programme Managers and Engineers: Applying The Guidelines Along The Sanitation Ladder, Geneva: WHO.

WHO (2016) Sanitation Safety Planning [online], Geneva: WHO $<$ https://www.who.int/water_sanitation_health/publications/ssp-manual/en/> [accessed 10 April 2019].

WHO (2017) Progress on Drinking Water, Sanitation and Hygiene, Joint Monitoring Programme, Geneva: World Health Organization.

Worku, Y. and Muchie, M. (2012) 'An attempt at quantifying factors that affect efficiency in the management of solid waste produced by commercial businesses in the city of Tshwane, South Africa', Journal of Environmental and Public Health 2012: 165353

<http://dx.doi.org/10.1155/2012/165353>. 


\section{BASED SANITATION}

\section{[A]Annex 1}

[CAP]Figure A1 System mapping capturing processes and activities in India and London CBS systems

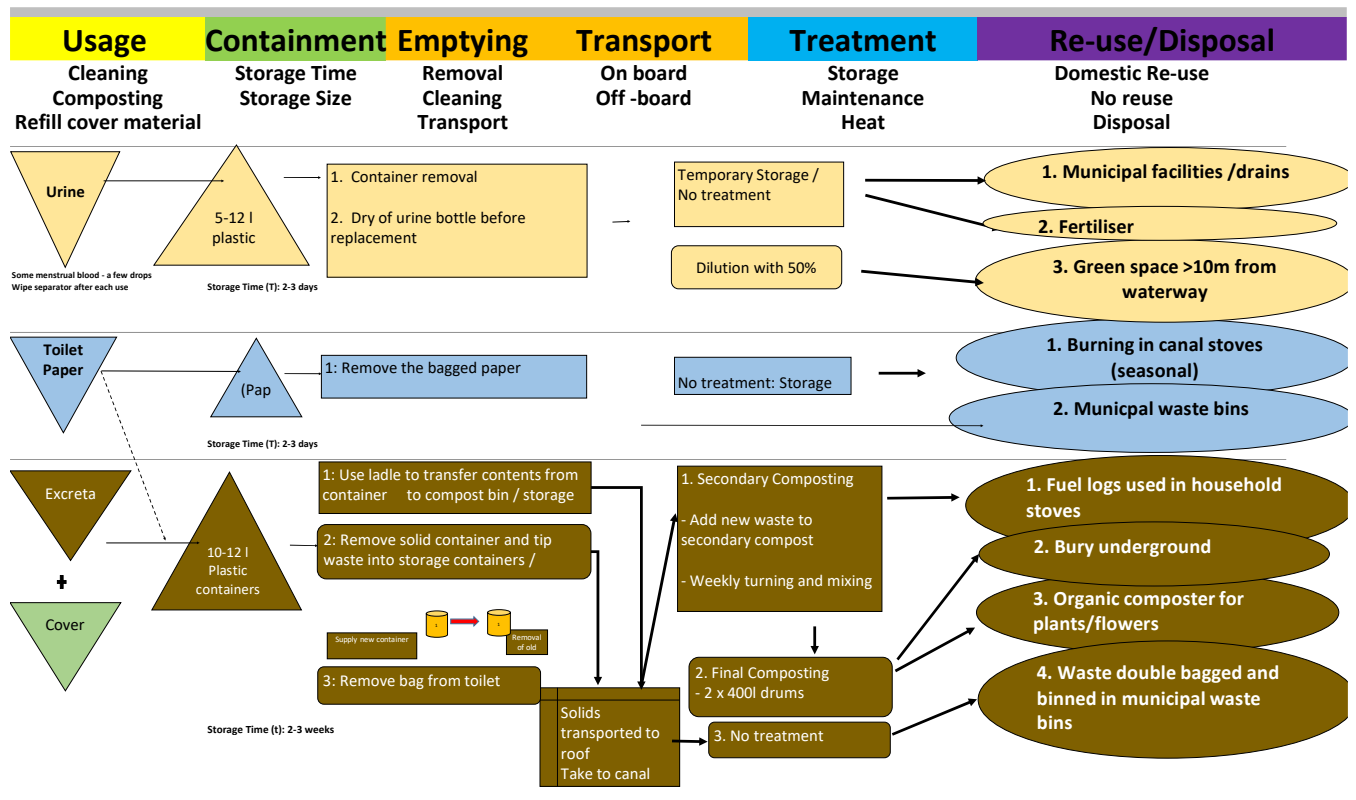

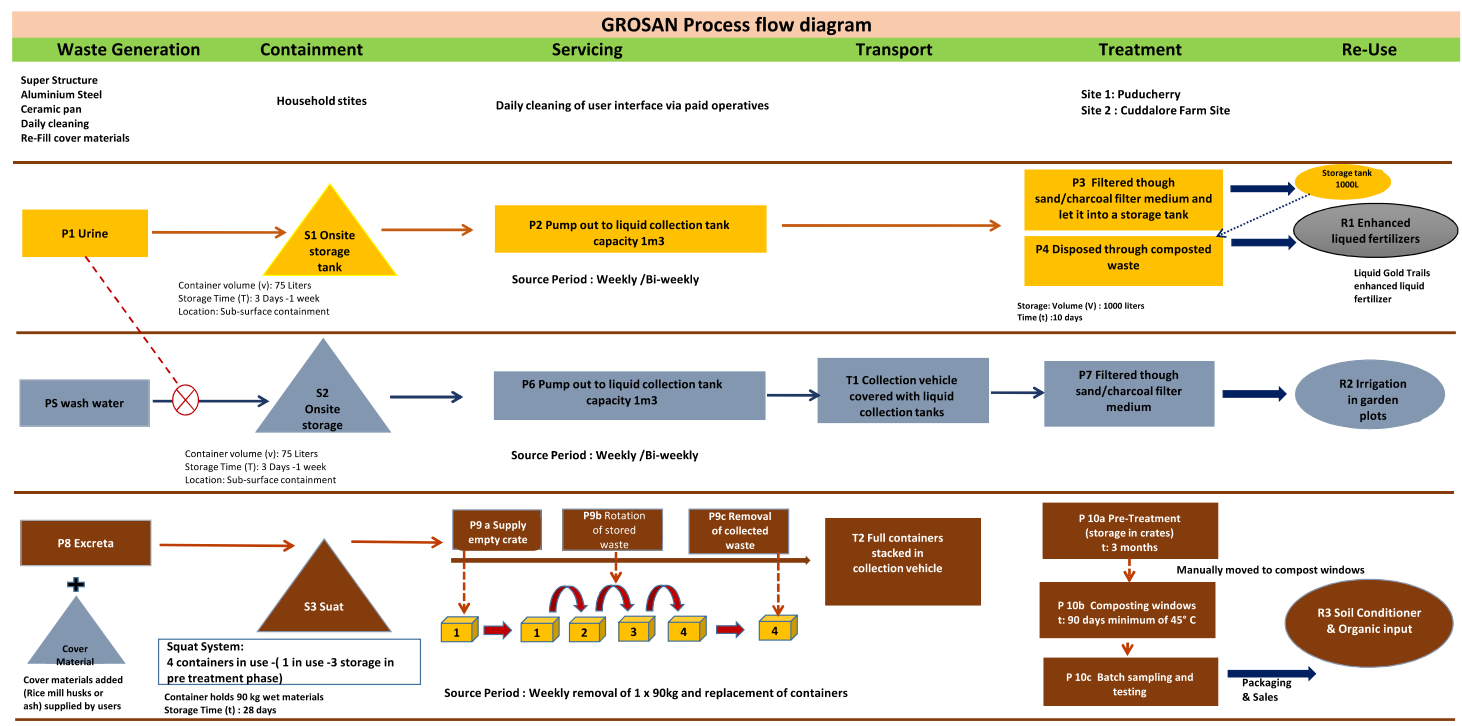




\section{BASED SANITATION}

[A]Annex 2

[CAP]Table A1 Minimum design standards

\begin{tabular}{|c|c|c|}
\hline \multicolumn{3}{|c|}{ Toilet design - front end, collection container } \\
\hline Cleanability & 1 & Contact surfaces are smooth, non-porous, and easy to clean \\
\hline & 2 & Contact surface are easily available for cleaning \\
\hline & 3 & Toilet surfaces can be cleaned without disassembly \\
\hline & 4 & No dead spaces, recesses, hard to clean areas \\
\hline & 5 & No sharp angles/inadequately rounded corners $<1 \mathrm{~cm}$ \\
\hline Durability & 6 & Materials (highly durable, durable, not durable) \\
\hline \multirow[t]{3}{*}{ Usability } & 7 & Normal use doesn't involve hands going near excreta \\
\hline & 8 & Separator design prevents faecal deposits landing on separator \\
\hline & 9 & Urine pipe wide enough to not block easily $>32 \mathrm{~mm}$ minimum diameter \\
\hline Child adapted design & 10 & Smaller seat and/or drop hole $(<25 \mathrm{~cm})$ for child use \\
\hline \multirow[t]{2}{*}{$\begin{array}{l}\text { Isolation and containment } \\
\text { (SFW) }\end{array}$} & 11 & Any spillage contained within toilet unit \\
\hline & 12 & Drop hole closed when not in use \\
\hline $\begin{array}{l}\text { Isolation and containment } \\
\text { (LFW) }\end{array}$ & 13 & Any spillage contained or dispersed into environment safely \\
\hline $\begin{array}{l}\text { Minimum dispersal through } \\
\text { air }\end{array}$ & 14 & Sealed containers when full prevents dispersion through air \\
\hline $\begin{array}{l}\text { Risk signage and } \\
\text { communication }\end{array}$ & 15 & Appropriate IEC standard when toilet is in use (visible, relevant) \\
\hline \multicolumn{3}{|l|}{ Toilet installation } \\
\hline \multirow[t]{2}{*}{ Cleanability } & 1 & Floors are non-absorbent, easy to clean, and washable \\
\hline & 2 & Floors surfaces \\
\hline Durability & 3 & Materials of construction are durable \\
\hline \multirow[t]{4}{*}{ Usability } & 4 & Access to anal cleansing materials (paper or water) \\
\hline & 5 & Handwashing point is present with soap and water \\
\hline & 6 & Cover material is present \\
\hline & 7 & Cover material is appropriate \\
\hline Disabled access & 8 & Toilet is accessible for people living with disability (height, size, steps) \\
\hline Child adapted design & 9 & Toilet is accessible for children (height, size, steps) \\
\hline $\begin{array}{l}\text { Isolation and containment } \\
\text { (SFW) }\end{array}$ & 10 & Full containers are sealed and watertight \\
\hline \multirow[t]{3}{*}{$\begin{array}{l}\text { Isolation and containment } \\
\text { (LFW) }\end{array}$} & 11 & Full containers are sealed and watertight \\
\hline & 12 & A soakaway is installed for waste water/urine if not collected \\
\hline & 13 & Soakaway installed minimum distance of $>30 \mathrm{~m}$ from a water point \\
\hline $\begin{array}{l}\text { Minimum dispersal through } \\
\text { air }\end{array}$ & 14 & Toilet installed $>10 \mathrm{~m}$ from food preparation areas \\
\hline $\begin{array}{l}\text { Risk signage and } \\
\text { communication }\end{array}$ & 15 & Appropriate IEC standard when toilet is in use (visible, relevant) \\
\hline
\end{tabular}




\section{BASED SANITATION}

\begin{tabular}{|c|c|c|}
\hline Cleanability & 1 & Contact surfaces are smooth, non-porous, and easy to clean \\
\hline & 2 & Contact surfaces are easily available for cleaning \\
\hline Durability & 3 & Materials (highly durable, durable, not durable) \\
\hline \multirow[t]{3}{*}{ Usability } & 4 & Solids containers not bigger $<22 \mathrm{~L}$ to enable safe handling \\
\hline & 5 & Handles/straps to facilitate lifting \\
\hline & 6 & Handling tools to prevent direct manual handling \\
\hline $\begin{array}{l}\text { Isolation and containment } \\
\text { (SFW) }\end{array}$ & 7 & Covered collection vehicle and sealed \\
\hline \multirow[t]{2}{*}{$\begin{array}{l}\text { Isolation and containment } \\
\text { (LFW) }\end{array}$} & 8 & Water-tightness of vehicle floor \\
\hline & 9 & Speed restriction on vehicle \\
\hline \multirow[t]{2}{*}{$\begin{array}{l}\text { Risk signage and } \\
\text { communication }\end{array}$} & 10 & Biological hazard (signs) to inform public of bio-hazard \\
\hline & 11 & Emergency response kit on board \\
\hline \multicolumn{3}{|l|}{ Treatment facility } \\
\hline \multirow[t]{3}{*}{ Cleanability } & 1 & Non-absorbent, easy to clean surfaces of wash down areas \\
\hline & 2 & $\begin{array}{l}\text { Non-absorbent, easy to clean floor surfaces in high risks areas for } \\
\text { environmental contamination }\end{array}$ \\
\hline & 3 & Drainage adequate to allow flow of water \\
\hline \multirow[t]{4}{*}{ Usability } & 4 & $\begin{array}{l}\text { Handwashing stations and disinfection points are well labelled and } \\
\text { available in effective numbers }\end{array}$ \\
\hline & 5 & $\begin{array}{l}\text { Contaminated and non-contaminated areas are separated into high and } \\
\text { low risk areas }\end{array}$ \\
\hline & 6 & $\begin{array}{l}\text { Cleaning and disinfection process does not result in splashing and } \\
\text { direct ingestion of waste water }\end{array}$ \\
\hline & 7 & $\begin{array}{l}\text { 'Close-contact' manipulation by front line staff of the faecal and urine } \\
\text { waste materials is minimized }\end{array}$ \\
\hline \multirow[t]{2}{*}{$\begin{array}{l}\text { Isolation and containment } \\
\text { (SFW) }\end{array}$} & 8 & $\begin{array}{l}\text { A physical fly barrier or adequate steps are taken to prevent excessive } \\
\text { flies in the treatment area }\end{array}$ \\
\hline & 9 & Stored waste is kept in sealed containers, until final disposal \\
\hline \multirow[t]{3}{*}{$\begin{array}{l}\text { Isolation and containment } \\
\text { (LFW) }\end{array}$} & 10 & Contaminated washing water \\
\hline & 11 & $\begin{array}{l}\text { An appropriate soakaway area or drainage system is installed for } \\
\text { grey/waste water }\end{array}$ \\
\hline & 12 & $\begin{array}{l}\text { A designed soakaway area or drainage system is well maintained and } \\
\text { operating effectively for contaminated grey/waste water }\end{array}$ \\
\hline \multirow[t]{2}{*}{$\begin{array}{l}\text { Minimum dispersal through } \\
\text { air }\end{array}$} & 13 & $\begin{array}{l}\text { Adequate ventilation when handling waste to prevent concentration of } \\
\text { dangerous particles }\end{array}$ \\
\hline & 14 & $\begin{array}{l}\text { All staff areas and eating areas are physically separate with hygiene } \\
\text { controls to prevent cross-contamination }\end{array}$ \\
\hline $\begin{array}{l}\text { Risk signage and } \\
\text { communication }\end{array}$ & 15 & Fence and public access barriers \\
\hline \multicolumn{3}{|c|}{ Liquid waste disposal facility - soakaway pits, drainage fields } \\
\hline Design & 1 & The soakaway is installed correctly to prevent seepage \\
\hline
\end{tabular}




\begin{tabular}{|c|c|c|}
\hline & 2 & $\begin{array}{l}\text { The soakaway area has a length to width ratio }>2: 1 \text { to allow solids to } \\
\text { settle }\end{array}$ \\
\hline & 3 & The soakaway is installed $>30 \mathrm{~m}$ from a potable water point \\
\hline & 4 & $\begin{array}{l}\text { The depth to the groundwater is }>3 \mathrm{~m} \text { from the bottom of the } \\
\text { soakaway pit }\end{array}$ \\
\hline Durability & 5 & The soakaway is built to sufficient standards \\
\hline \multirow[t]{3}{*}{ Usability } & 6 & Grease trap is accessible for maintenance \\
\hline & 7 & The soakaway has sufficient capacity for the input \\
\hline & 8 & The treatment system can accommodate increases in discharge inputs \\
\hline $\begin{array}{l}\text { Isolation and containment } \\
\text { (SFW) }\end{array}$ & 9 & Sludge is managed at end of final disposal \\
\hline $\begin{array}{l}\text { Isolation and containment } \\
\text { (LFW) }\end{array}$ & 10 & The discharge rate into the soakaway is controlled \\
\hline $\begin{array}{l}\text { Minimum dispersal through } \\
\text { air }\end{array}$ & 11 & There is no odour from the pit \\
\hline $\begin{array}{l}\text { Risk signage and } \\
\text { communication }\end{array}$ & 12 & Fence and public access barriers are erected around the soakaway pit \\
\hline
\end{tabular}


[A]Annex 3

[CAP]Table A2 System operational performance using a correct maintenance schedule for CBS systems

\begin{tabular}{|c|c|c|c|}
\hline Hardware item & $\begin{array}{l}\text { Frequen } \\
\text { cy }\end{array}$ & Component & Procedure \\
\hline \multirow{5}{*}{ Toilet unit } & Daily & $\begin{array}{l}\text { Unit (contact surfaces, floors, urine diversion, } \\
\text { squat plate) }\end{array}$ & $\begin{array}{l}\text { Cleaning with warm water, rinse, and disinfect with } 0.05 \% \\
\text { chlorine solution }\end{array}$ \\
\hline & & & Inspect area around unit and clean as required \\
\hline & Weekly & Storage containers & Inspect for closeness of lids, replace as required \\
\hline & Monthly & Urine diversion pipe, interior walls & Checking for build-up of salts, replacement if necessary \\
\hline & & & Cleaning inside walls, disinfection of unit \\
\hline \multirow{9}{*}{$\begin{array}{l}\text { Collection } \\
\text { equipment }\end{array}$} & After use & Collection containers (urine and faecal) & $\begin{array}{l}\text { Cleaning with warm water, rinse, and disinfect with } 0.05 \% \\
\text { chlorine solution }\end{array}$ \\
\hline & & & Inspect for wear and tear, cracks \\
\hline & After use & Vehicle & $\begin{array}{l}\text { Cleaning with warm water, rinse, and disinfect with } 0.05 \% \\
\text { chlorine solution }\end{array}$ \\
\hline & After use & PPE - gloves & Washing and disinfection with $0.05 \%$ chlorine solution \\
\hline & & & Inspect for holes, rips, replace as required \\
\hline & After use & PPE - overalls & Washing and disinfection with $0.05 \%$ chlorine solution \\
\hline & Weekly & Containers (urine and faecal) & test for water-tightness (fill and check for leaks) \\
\hline & & Seals (lids fixtures and fitting) & test for water-tightness (fill, turn inside out, and check for leaks) \\
\hline & & & Replace as required \\
\hline \multirow{5}{*}{$\begin{array}{l}\text { Treatment facility } \\
\text { equipment specific }\end{array}$} & Daily & Composting crates & Inspect for evidence of vector infestation \\
\hline & & & Lids present and fitted \\
\hline & & Screening equipment & Inspect for wear and tear, holes in the screens \\
\hline & & Windrows & Inspect for run-off \\
\hline & & & Covered \\
\hline
\end{tabular}




\begin{tabular}{|l|l|l|l|}
\multirow{5}{*}{} & Slow sand filter & Does not run dry \\
\cline { 2 - 4 } & & Handwashing equipment & Water and soap available \\
\cline { 2 - 4 } & Weekly & & \\
\cline { 2 - 4 } & & Compost crates & Date tags present/not sun damaged/replace \\
\cline { 2 - 4 } & Monthly & Temperature probes/logs & Inspection of biological schmutzdecke \\
\hline \multirow{2}{*}{ Disposal } & & Urine soakaway facility & Not blocked, cleaning grease trap \\
\cline { 2 - 4 } & Weekly & Incinerator & Removing ash \\
\hline
\end{tabular}

